\title{
Some biological parameters of Patella caerulea from the Black Sea
}

\author{
Mehmet Aydın ${ }^{1}$ (D) Ahmet Emir Şahin ${ }^{1}$ (D) Uğur Karadurmuş ${ }^{2^{*}}$ (D) \\ ${ }^{1}$ Ordu University, Fatsa Faculty of Marine Sciences, Department of Fisheries Technology Engineering, 52400, Ordu, Turkey \\ ${ }^{2}$ Bandırma Onyedi Eylül University, Maritime Vocational School, Department of Underwater Technology, 10200, Balıkesir, Turkey
}

\begin{tabular}{|c|c|}
\hline A R T I C L E I N F O & A B S T R A C T \\
\hline Article History: & Limpets are common inhabitants of the midlittoral and upper infralittoral zones and play an \\
\hline Received: 30.03 .2021 & important ecological role in the coastal ecosystem. The study aimed to assess growth, meat yield, \\
\hline Received in revised form: 30.04 .2021 & morphological aspects, condition and reproduction features of Patella caerulea. About $58 \%$ of \\
\hline Accepted: 30.04 .2021 & collected Mediterranean limpets were concentrated in the $25.0-34.9 \mathrm{~mm}$ shell length group. The \\
\hline Available online: 26.06 .2021 & average meat yield ratio was calculated as $39.34 \%$. Mean growth increments for shell length (SL) and \\
\hline Keywords: & total weight (TW) were $23.99 \%$ and $97.99 \%$, respectively. Results exhibited relatively high correlation \\
\hline Gastropod & coefficients among variables. Mean condition factor value was calculated as 14.2. Spawning occurs \\
\hline Growth & over a short period with ovigerous females observed on two month periods. Mean fecundity was \\
\hline Limpet & calculated as $90,983 \pm 28,675$ eggs/g whereas mean egg diameter was estimated as $160.6 \mu \mathrm{m}$. This study \\
\hline Morphometry & presents first baseline information about biological and morphological of Mediterranean Limpets \\
\hline Patellidae & population in Black Sea. \\
\hline
\end{tabular}

Please cite this paper as follows:

Aydın, M., Şahin, A. E., \& Karadurmuş, U. (2021). Some biological parameters of Patella caerulea from the Black Sea. Marine Science and Technology Bulletin, 10(4), 396-405. https://doi.org/10.33714/masteb.906225

\section{Introduction}

Marine gastropods are situated at several levels in the food chain, which increases their determining role in the functioning of marine ecosystems (Hakenkamp \& Morin, 2000). Limpets of the genus Patella are grazing gastropods, common inhabitants of the hard substrate communities in the mid-littoral and upper infralittoral zones of the East Atlantic and Mediterranean coasts in temperate latitudes (Vafidis et al., 2020). Limpets are considered the "keystone" species of the mid-littoral zone and

* Corresponding author

E-mail address: ukaradurmus@bandirma.edu.tr (U. Karadurmuş) are widely collected for human consumption and as fishing bait (Menge, 2000). They play an essential role in controlling algal coverage and consequently, the ecological succession and biological communities established in coastal zones (Prusina et al., 2015; Vafidis et al., 2020).

The Mediterranean limpet Patella caerulea Linnaeus, 1758 is among the most common species of rocky shores in the infralittoral and midlittoral, especially Mediterranean (Küçükdermenci et al., 2017). P. caerulea is considered endemic to the Mediterranean Sea (Christiaens, 1973). It is very 
prevalent in Turkish seawater (Öztürk \& Ergen, 1996). This species primarily feed by scraping algae off rocks and plants such as Cyanophyceae, Ulva lactuca, Corallina elongate (Silva et al., 2008; Ayas, 2010). P. caerulea is a hermaphrodite protandric species and may reach a length of $70 \mathrm{~mm}$ (Kastanevakis et al., 2008). Mediterranean limpet fulfills the criterion an ideal bioindicator for heavy metal contamination is extensively used in marine monitoring programs (Storelli \& Marcotrigiano, 2005).

Various studies have been conducted on the morphology, biology, ecology, and distribution of Patella species, especially in the Mediterranean Sea (Navarro et al., 2005; Espinosa et al., 2006; Prusina et al., 2014; Prusina et al., 2015; Bouzaza \& Mezali, 2018). In Turkey, generally, morphometric, taxonomic, distribution, and heavy metals content studies on P. caerulea have been conducted (Bat et al., 1999; Akşit \& Falakalı Mutaf, 2007; Ayas, 2010; Çulha \& Bat, 2010). Although P. caerulea is the most dominant intertidal gastropod on the rocky shore of the Black Sea in Turkey, there is no information about these species in the region yet. The present study aims to make an extensive assessment of population structure and characteristics, growth, meat yield and reproductive status of $P$. caerulea in the Black Sea. To our knowledge, this is the first study in Turkey of the species, on the Black Sea.

\section{Material and Methods}

\section{Study Area and Sampling}

This study was conducted along the Turkish coast of the Black Sea (between $41.149538^{\circ} \mathrm{N}, 37.273525^{\circ} \mathrm{E}-40.971953^{\circ} \mathrm{N}$, $\left.38.059734^{\circ} \mathrm{E}\right)$. In this study, $P$. caerulea were collected from the intertidal zone of the coastline monthly from April 2018 to March 2019. Limpets were collected by hand with a penknife, and injured limpets (broken, shattered, severed) were not included in the sampling. Collected specimens were put into drums filled with seawater and then transferred to the laboratory. Collected samples were identified on the basis of form and external sculpture of the shell, the color of the pallial tentacles and the color of the foot (Christiaens, 1973).

\section{Growth and Morphological Analyses}

Shell length (SL - the longest distance between the anterior and posterior of limpet), shell width ( $\mathrm{SWi}$ - the longest distance perpendicular to the anterior-posterior axis), and shell height ( $\mathrm{SH}$ - the longest vertical distance from the apex to the shell base) of samples were measured using a digital caliper to the nearest $0.01 \mathrm{~mm}$. Total wet weight (TW), meat weight (MW), and shell weight (SWe) was measured with an electronic balance of $0.001 \mathrm{~g}$ accuracy. The growth performance of samples according to $S L$ and $T W$ was determined with the formula below:

$$
\begin{aligned}
& \text { SL increment }(\%)=\left[\left(S L_{n}-S L_{n-1}\right) / S L_{n-1}\right] \times 100 \\
& \text { TW increment }(\%)=\left[\left(T W_{n}-T W_{n-1}\right) / T W_{n-1}\right] \times 100
\end{aligned}
$$

where $n$ is the number of size classes (Ricker, 1975). The SL, $S W i$ and $S H$ relationships with each one were determined using the equation (3).

$$
W=a L^{b}
$$

Linear relationships between $S L$ and $T W, S W e$, and $M W$ were also analyzed (Le Cren, 1951; Pauly, 1980; Erkoyuncu, 1995). The condition factor $(K)$ was calculated using the formula (Equation 4):

$$
K=100 \times \frac{T W}{S L^{3}}
$$

where $T W$ was total weight $(\mathrm{g})$, and SL was shell length (mm) of collected samples (Bagenal, 1978).

\section{Reproduction, Fecundity, and Egg Diameter}

Sex was determined using macroscopic methods. The spawning period was determined by analyzing the monthly variation in the gonad maturity as well as the gonadosomatic index (GSI). In this study, 191 females were used to calculate the gonadosomatic index as described by (Bagenal, 1978) (Equation 5):

$$
G S I=\left[\left(\frac{\text { Gonad weight }}{\text { Meat weight }}\right) \times 100\right]
$$

The limpet eggs were removed from 26 ovigerous females in the spawning period (in October and November), and the total weight of eggs was measured using a balance with a sensitivity of $0.0005 \mathrm{~g}$. Fifty eggs were taken from different regions of an ovary, and egg diameters were measured with an calibrated ocular micrometer. Eggs were counted with an ocular micrometer as (Equation 6):

$$
F=n\left(\frac{W_{0}}{X}\right)
$$

where $W_{0}$ denotes the weight of gonad and $n$ represents the number of eggs in the subsample, $X$ stands for subsample weight (g), $F$ represents the number of eggs (Bagenal, 1978; Kwei, 1978; Jones et al., 1990).

\section{Data Analysis}

Statistics and data analyses were performed by statistical software SPSS v26.0. The normality of the data was checked 
using the Kolmogorov-Smirnov test, depending on the sample size. In the former analysis, homogeneity of variance was tested using Levene's test. Since the data in this study were not normally distributed, monthly morphological values were compared using the Mann-Whitney U-test. Monthly and combined variables were analyzed with the Pearson correlation and regression analysis to investigate the relationships among morphological characters (Sokal \& Rohlf, 1969; Düzgüneş et al., 1983). Hierarchical Ward cluster analysis after $Z$ score correction was used to determine closely related variables (Lopez et al., 2004). The sex ratio of samples, the expected 1:1 male to female ratio was assessed using the chi-square $\left(\chi^{2}\right)$ test (Düzgüneş et al., 1983).

\section{Results and Discussion}

\section{Size Distribution and Meat Yield}

In the present study, $1830 \mathrm{P}$. caerulea individuals were sampled during the study period. Shell length distribution of collected samples showed that $57.98 \%$ of Mediterranean limpets were in a range of 25 to $34.9 \mathrm{~mm}$. It was observed that $77.40 \%$ of the samples collected were smaller than $5 \mathrm{~g}$, according to the TW (Figure 1). Ayas et al. (2008) reported the $\mathrm{SL}, \mathrm{SWi}$, and $\mathrm{SH}$ in a range of $19-39 \mathrm{~mm}, 15-33 \mathrm{~mm}$ and 5-11 $\mathrm{mm}$ from samples caught in the Mersin Bay (Mediterranean). Küçükdermenci et al. (2017) reported the minimum and maximum SL as 24.4 and $30.7 \mathrm{~mm}$ in Izmir Bay (Aegean Sea), respectively. Vafidis et al. (2020), who conducted a study in the Pagasitikos Bay (Aegean Sea), determined the average SL, SWi, and $\mathrm{SH}$ as 23.36, 18.96, and $6.35 \mathrm{~mm}$, respectively. In our study, biometric parameters were more variable compared to similar

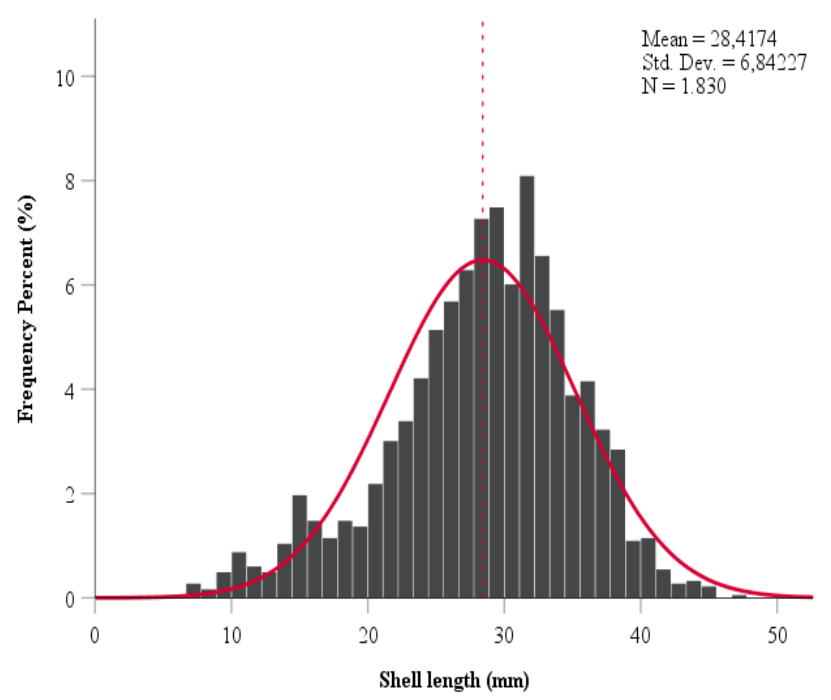

studies, possibly attributed to variation in the number of samples or sampling regions. The environmental and ecological factors (food availability, water parameters, and meteorological factors) may lead to morphological variations in limpets of the same species that live in different ecosystems (Crothers, 1983). Monthly biometric measurements and statistical differences of $P$. caerulea are presented in Table 1 . A closer look at the monthly SL reveals that the maximum value was $31.70 \mathrm{~mm}$ in December and the minimum value of $25.80 \mathrm{~mm}$ in May. Minimum SL, SWi, SH, TW, and MW were determined in May and July. High SL, SWe, TW, and SW values were obtained in April and December.

Average MW of $P$. caerulea was calculated as $1.49 \pm 0.02 \mathrm{~g}$ with a rate of $39.34 \%$ of TW. In other words, $1 \mathrm{~kg}$ of edible meat can be obtained from approximate the $2.5 \mathrm{~kg}$ live weight of $P$. caerulea. It was determined that the minimum and maximum meat yield ratio was $35.32 \%$ in November and $43.68 \%$ in August, respectively. A weak relationship was found between the SL and MW. However, the maximum ratio of meat weight (41.56\%) was observed in the 25.0-29.9 $\mathrm{mm}$ shell length classes (Figure 2). The mean meat weight of samples was significantly different by month $\left(\chi^{2}=99.851 ; \mathrm{df}=11 ; .001\right)$. Similarly, Küçükdermenci et al. (2017) determined the percentage of meat yield as $37 \%$ in Izmir (Turkey) for P. caerulea. Hamad et al. (2019) who conducted a study in Libya, determined the average meat yield as $1.09 \mathrm{~g}$. The present study's findings concerning meat yield are in agreement with the findings reported by Küçükdermenci et al. (2017) and Hamad et al. (2019). Water conditions, especially temperature, may also affect the meat yield of Patella species (Fretter \& Graham, 1976). Thus, it is usual to observe differences in meat yield.



Figure 1. Density histogram of shell length (SL) and total weight (TW) of population and dashed red lines indicating the means and red lines representing the normal curve of the population for the $P$. caerulea 
Table 1. Monthly and totally morphometric measurement values of Patella caerulea $(\mathrm{N}=1830)$

\begin{tabular}{|c|c|c|c|c|c|c|c|c|c|c|c|c|c|c|}
\hline & & $\begin{array}{c}\text { April } \\
\text { A }\end{array}$ & $\begin{array}{c}\text { May } \\
\text { B }\end{array}$ & $\begin{array}{c}\text { June } \\
\text { C }\end{array}$ & $\begin{array}{c}\text { July } \\
\text { D }\end{array}$ & $\begin{array}{c}\text { Aug } \\
\text { E }\end{array}$ & $\begin{array}{c}\text { Sep } \\
\text { F }\end{array}$ & $\begin{array}{c}\text { Oct } \\
\text { G }\end{array}$ & $\begin{array}{c}\text { Nov } \\
\mathbf{H}\end{array}$ & $\begin{array}{c}\text { Dec } \\
\text { I }\end{array}$ & $\begin{array}{c}\text { Jan } \\
\text { J }\end{array}$ & $\begin{array}{c}\text { Feb } \\
\mathrm{K}\end{array}$ & $\begin{array}{c}\text { Mar } \\
\text { L }\end{array}$ & Mean \\
\hline \multirow{5}{*}{$\mathrm{SL}(\mathrm{mm})$} & Mean & 31.04 & 25.80 & 28.46 & 26.20 & 28.84 & 28.65 & 28.51 & 28.53 & 31.70 & 28.54 & 26.74 & 27.66 & 28.42 \\
\hline & $\pm \mathrm{SE}$ & 0.54 & 0.71 & 0.51 & 0.41 & 0.38 & 0.44 & 0.68 & 0.56 & 0.49 & 0.57 & 0.54 & 0.61 & 0.16 \\
\hline & Min & 7.26 & 6.31 & 9.84 & 10.13 & 15.99 & 9.27 & 6.72 & 7.75 & 10.09 & 10.33 & 9.32 & 12.10 & 6.31 \\
\hline & Max & 44.29 & 43.42 & 40.43 & 43.35 & 38.72 & 47.05 & 44.75 & 45.00 & 43.02 & 45.26 & 38.86 & 40.40 & 47.05 \\
\hline & Dif. & $\mathrm{a}, \mathrm{f}, \mathrm{g}$ & $b, c$ & $\mathrm{~b}, \mathrm{~d}, \mathrm{e}$ & c & $\mathrm{a}, \mathrm{d}, \mathrm{h}, \mathrm{i}$ & $\mathrm{a}, \mathrm{e}, \mathrm{h}, \mathrm{i}$ & $\mathrm{a}, \mathrm{b}, \mathrm{c}$ & $\mathrm{a}, \mathrm{b}, \mathrm{c}$ & f & $\mathrm{b}, \mathrm{c}, \mathrm{d}, \mathrm{e}, \mathrm{g}$ & $\mathrm{b}, \mathrm{c}, \mathrm{h}$ & $\mathrm{b}, \mathrm{c}, \mathrm{i}$ & $* *$ \\
\hline \multirow{5}{*}{ SWi (mm) } & Mean & 25.14 & 20.62 & 22.92 & 20.91 & 23.17 & 23.22 & 23.12 & 23.15 & 26.03 & 23.22 & 21.51 & 22.51 & 22.99 \\
\hline & $\pm \mathrm{SE}$ & 0.46 & 0.61 & 0.46 & 0.36 & 0.33 & 0.39 & 0.61 & 0.50 & 0.44 & 0.50 & 0.47 & 0.55 & 0.14 \\
\hline & Min & 4.82 & 4.09 & 6.61 & 7.23 & 12.13 & 6.53 & 5.03 & 5.38 & 7.47 & 7.15 & 6.30 & 8.55 & 4.09 \\
\hline & Max & 35.98 & 35.78 & 36.26 & 36.85 & 31.18 & 38.12 & 39.02 & 36.49 & 36.49 & 38.04 & 32.94 & 35.53 & 39.02 \\
\hline & Dif. & $\mathrm{a}, \mathrm{h}, \mathrm{i}$ & $b, d, g, j$ & $\mathrm{~b}, \mathrm{c}, \mathrm{e}$ & d & e & $\mathrm{a}, \mathrm{e}, \mathrm{f}$ & $\mathrm{a}, \mathrm{b}, \mathrm{d}, \mathrm{e}$ & $\mathrm{a}, \mathrm{c}, \mathrm{e}, \mathrm{g}$ & $\mathrm{h}$ & $c, e, i, j$ & $\mathrm{~b}, \mathrm{~d}, \mathrm{e}$ & $\mathrm{b}, \mathrm{d}, \mathrm{e}$ & $* *$ \\
\hline \multirow{5}{*}{$\mathrm{SH}(\mathrm{mm})$} & Mean & 10.46 & 9.10 & 10.05 & 9.09 & 10.10 & 10.31 & 10.84 & 10.49 & 10.85 & 9.75 & 9.49 & 9.72 & 10.04 \\
\hline & $\pm \mathrm{SE}$ & 0.23 & 0.31 & 0.25 & 0.19 & 0.17 & 0.21 & 0.34 & 0.25 & 0.20 & 0.23 & 0.22 & 0.27 & 0.07 \\
\hline & Min & 2.29 & 1.54 & 2.94 & 2.64 & 4.83 & 2.35 & 1.14 & 1.71 & 3.22 & 2.61 & 2.67 & 3.15 & 1.14 \\
\hline & Max & 15.64 & 17.10 & 18.85 & 15.57 & 14.88 & 19.15 & 22.81 & 17.69 & 15.60 & 16.91 & 15.67 & 18.23 & 22.81 \\
\hline & Dif. & $\mathrm{a}, \mathrm{e}, \mathrm{f}, \mathrm{g}$ & $b, c, d$ & $\mathrm{a}, \mathrm{b}$ & $\mathrm{b}$ & $\mathrm{a}, \mathrm{c}, \mathrm{e}, \mathrm{f}, \mathrm{g}$ & $\mathrm{a}, \mathrm{d}, \mathrm{e}, \mathrm{f}, \mathrm{g}$ & $\mathrm{a}, \mathrm{e}, \mathrm{f}, \mathrm{g}$ & $\mathrm{a}, \mathrm{e}, \mathrm{f}, \mathrm{g}$ & a & b,e & $\mathrm{b}, \mathrm{f}$ & $b, g$ & ** \\
\hline \multirow{5}{*}{ TW (g) } & Mean & 4.93 & 3.30 & 4.08 & 3.00 & 3.76 & 4.08 & 3.93 & 3.91 & 4.51 & 3.75 & 3.16 & 3.55 & 3.84 \\
\hline & $\pm \mathrm{SE}$ & 0.21 & 0.23 & 0.21 & 0.13 & 0.14 & 0.17 & 0.26 & 0.21 & 0.17 & 0.20 & 0.17 & 0.21 & 0.06 \\
\hline & Min & 0.06 & 0.02 & 0.10 & 0.10 & 0.51 & 0.12 & 0.04 & 0.04 & 0.14 & 0.15 & 0.08 & 0.24 & 0.02 \\
\hline & Max & 14.62 & 11.87 & 10.75 & 10.41 & 7.88 & 12.47 & 15.05 & 13.97 & 10.39 & 12.02 & 8.90 & 13.44 & 15.05 \\
\hline & Dif. & a & $b, c, d$ & $\mathrm{a}, \mathrm{b}, \mathrm{d}$ & c & $\mathrm{d}, \mathrm{g}, \mathrm{i}, \mathrm{j}$ & $a, d, e, j$ & $\mathrm{a}, \mathrm{b}, \mathrm{c}, \mathrm{d}$ & $\mathrm{a}, \mathrm{d}, \mathrm{f}, \mathrm{i}, \mathrm{j}$ & $\mathrm{a}, \mathrm{g}, \mathrm{h}$ & $\mathrm{b}, \mathrm{c}, \mathrm{d}, \mathrm{h}$ & $c, \mathrm{i}$ & $b, c, j$ & $* *$ \\
\hline \multirow{5}{*}{ SWe (g) } & Mean & 2.23 & 1.56 & 1.78 & 1.31 & 1.66 & 1.78 & 1.79 & 1.85 & 2.22 & 1.75 & 1.48 & 1.68 & 1.76 \\
\hline & $\pm \mathrm{SE}$ & 0.10 & 0.12 & 0.09 & 0.06 & 0.06 & 0.07 & 0.12 & 0.10 & 0.09 & 0.10 & 0.08 & 0.10 & 0.03 \\
\hline & Min & 0.02 & 0.01 & 0.04 & 0.04 & 0.25 & 0.05 & 0.02 & 0.02 & 0.08 & 0.06 & 0.05 & 0.11 & 0.01 \\
\hline & Max & 6.71 & 6.67 & 5.71 & 5.10 & 4.24 & 5.20 & 6.49 & 7.08 & 5.55 & 5.57 & 4.87 & 7.58 & 7.58 \\
\hline & Dif. & $a, i, j$ & $\mathrm{~b}, \mathrm{~d}, \mathrm{e}$ & $\mathrm{a}, \mathrm{b}, \mathrm{c}, \mathrm{e}$ & d & e & $e, f$ & $\mathrm{a}, \mathrm{e}, \mathrm{g}, \mathrm{i}$ & $\mathrm{a}, \mathrm{e}, \mathrm{h}, \mathrm{i}$ & $\mathrm{i}$ & $c, e, j$ & $\mathrm{~b}, \mathrm{~d}, \mathrm{e}$ & $\mathrm{b}, \mathrm{d}, \mathrm{e}$ & $* *$ \\
\hline \multirow{5}{*}{ MW (g) } & Mean & 1.85 & 1.24 & 1.68 & 1.20 & 1.64 & 1.69 & 1.61 & 1.37 & 1.60 & 1.40 & 1.20 & 1.39 & 1.49 \\
\hline & $\pm \mathrm{SE}$ & 0.08 & 0.09 & 0.09 & 0.06 & 0.06 & 0.07 & 0.10 & 0.07 & 0.06 & 0.07 & 0.06 & 0.08 & 0.02 \\
\hline & Min & 0.02 & 0.01 & 0.05 & 0.04 & 0.20 & 0.04 & 0.01 & 0.01 & 0.05 & 0.05 & 0.03 & 0.10 & 0.01 \\
\hline & Max & 5.19 & 4.52 & 4.38 & 4.38 & 3.44 & 5.90 & 5.37 & 4.05 & 3.46 & 4.23 & 3.87 & 4.57 & 5.90 \\
\hline & Dif. & a & $\mathrm{b}, \mathrm{d}, \mathrm{h}$ & $\mathrm{a}, \mathrm{e}, \mathrm{g}, \mathrm{i}$ & $b, c$ & $\mathrm{a}, \mathrm{e}, \mathrm{g}, \mathrm{i}$ & $\mathrm{a}, \mathrm{e}, \mathrm{g}, \mathrm{i}$ & $\mathrm{a}, \mathrm{d}, \mathrm{e}, \mathrm{g}, \mathrm{i}$ & $\mathrm{b}, \mathrm{e}, \mathrm{fh}$ & $\mathrm{a}, \mathrm{f}, \mathrm{g}, \mathrm{i}$ & $\mathrm{b}, \mathrm{g}, \mathrm{h}$ & $c, \mathrm{~h}$ & $\mathrm{~b}, \mathrm{~h}, \mathrm{i}$ & $* *$ \\
\hline
\end{tabular}

Note: Superscript and capital letters denote comparisons between two months (a capital and a superscript). There is no statistical difference between a capital letter and each superscript letter $(\mathrm{P}<0.05)$. A - November, B - December, C - January, D - February, E - March, F - April, G - May, H - June, I - July, J - August, K - September, L - October. 
Table 2. Proximity matrix of six morphometric variables for P. caerulea

\begin{tabular}{|c|c|c|c|c|c|c|}
\hline \multicolumn{7}{|c|}{ Proximity Matrix } \\
\hline & SL & SWi & $\mathrm{SH}$ & TW & $\mathrm{SWe}$ & MW \\
\hline SL & 0.00 & & & & & \\
\hline SWi & 435.36 & 0.00 & & & & \\
\hline $\mathrm{SH}$ & 4582.08 & 2252.68 & 0.00 & & & \\
\hline TW & 8306.20 & 5012.97 & 578.12 & 0.00 & & \\
\hline SWe & 9614.60 & 6047.51 & 946.03 & $62.59^{\star}$ & 0.00 & \\
\hline MW & 9788.57 & 6188.20 & 1001.81 & $79.88^{\star}$ & $3.39^{*}$ & 0.00 \\
\hline
\end{tabular}

Note: Values with ${ }^{\star}$ indicates that the morphometric characters are very close.

Table 3. Mean $( \pm \mathrm{SE})$ and size increment rates $(\%)$ of SL $(\mathrm{mm})$ and $\mathrm{TW}(\mathrm{g})$ for sampled $P$. caerulea during the study

\begin{tabular}{|c|c|c|c|c|c|c|}
\hline Size classes & $\mathbf{N}$ & $\%$ & Mean SL & Mean TW & SL increment (\%) & TW increment (\%) \\
\hline $5.00-9.99$ & 18 & 0.98 & $8.52 \pm 0.26$ & $0.08 \pm 0.01$ & - & - \\
\hline $10.00-14.99$ & 72 & 3.93 & $12.89 \pm 0.19$ & $0.30 \pm 0.01$ & 51.18 & 264.85 \\
\hline $15.00-19.99$ & 119 & 6.50 & $17.36 \pm 0.14$ & $0.70 \pm 0.02$ & 34.73 & 136.81 \\
\hline $20.00-24.99$ & 275 & 15.03 & $22.86 \pm 0.08$ & $1.69 \pm 0.03$ & 31.69 & 141.99 \\
\hline $25.00-29.99$ & 539 & 29.45 & $27.65 \pm 0.06$ & $3.09 \pm 0.03$ & 20.95 & 82.43 \\
\hline $30.00-34.99$ & 522 & 28.52 & $32.34 \pm 0.06$ & $4.88 \pm 0.05$ & 16.95 & 58.10 \\
\hline $35.00-39.99$ & 238 & 13.01 & $37.01 \pm 0.08$ & $7.39 \pm 0.11$ & 14.43 & 51.39 \\
\hline $40.00-44.99$ & 43 & 2.35 & $41.62 \pm 0.20$ & $9.93 \pm 0.30$ & 12.46 & 34.35 \\
\hline $45.00-49.99$ & 4 & 0.22 & $45.59 \pm 0.49$ & $11.32 \pm 1.05$ & 9.54 & 13.92 \\
\hline Combined & 1830 & 100 & $28.42 \pm 0.16$ & $3.84 \pm 0.06$ & 23.99 & 97.98 \\
\hline
\end{tabular}

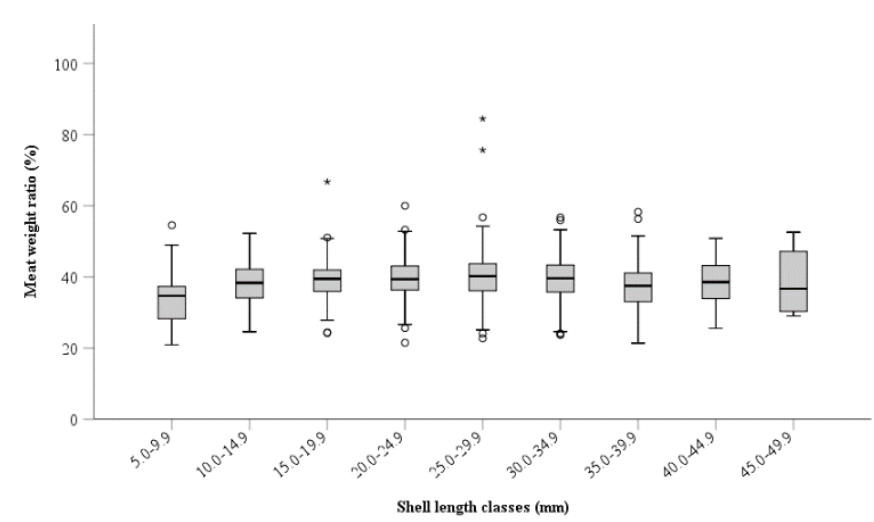

Figure 2. Boxplot of the percentage of meat weight (\%) for the Mediterranean limpets according to shell length classes. The whiskers represent the ranges for the bottom $25 \%$ and the top $25 \%$ of the data values while bold horizontal lines represent the mean values. Circles and stars outside the whisker represent outliers (95\%).

\section{Biometric Relationships and Growth}

According to the proximity matrix, close relationships were exhibited between SWe and MW (3.39), TW and SWe (62.59), and TW and MW (79.88). For instance, the relationships of SL with SWe and MW were highly distant. However, there appeared to be weak relationships of SL and SWi with other variables, a tendency similar to that presented by the correlation analysis (Table 2, Figure 3).

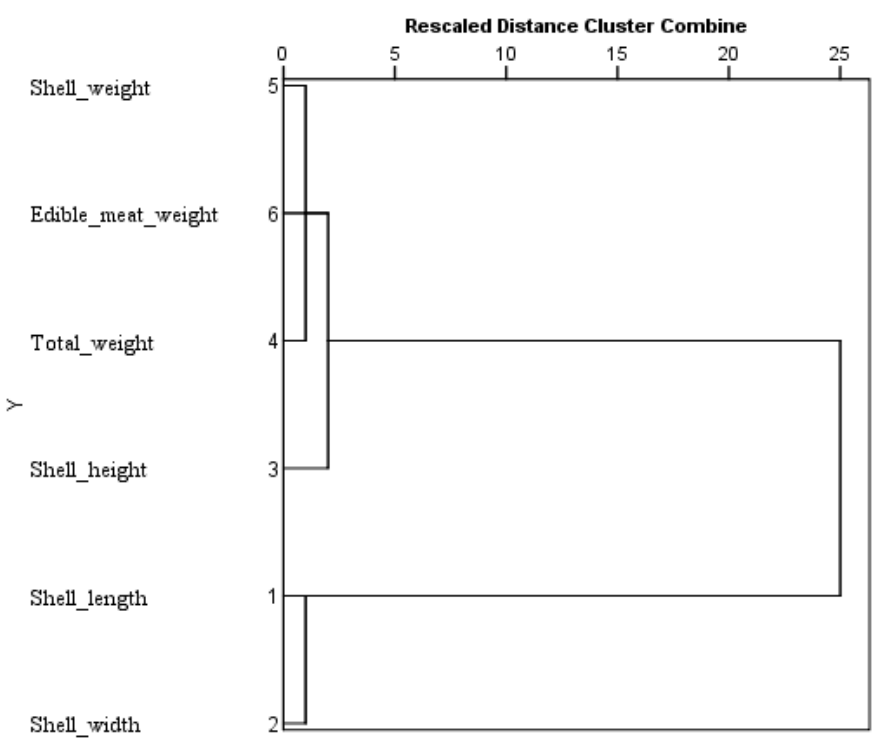

Figure 3. Dendrogram topology of the morphometric variables of $P$. caerulea.

The mean growth increment value was calculated as $23.99 \%$ and $97.99 \%$ according to the SL and TW, respectively. 
According to SL and TW growth increments, the highest growth $(51.18 \%$ and $264.85 \%$, respectively) occurred in 10.0-14.9 mm size class individuals (Table 3). Both growth types inversely correlated with the size classes but seemed to be close relations. Furthermore, the growth of individuals decreased with the increase of SL size classes and almost plateaued after $50 \mathrm{~mm}$. The most remarkable difference between SL and TW increments concerning the models is that the TW growth increment increases after $40 \mathrm{~g}$ weight classes (Figure 4).

In this study, the finding showed that the correlation coefficients among variables were quite high (Table 4). According to Pearson correlation values, the strongest and weakest correlations were determined between SL and SWi $\left(\mathrm{R}^{2}=0.982\right)$ and between ST and MW $\left(\mathrm{R}^{2}=0.868\right)$, respectively. A linear relationship and strong interaction $\left(\mathrm{R}^{2}=0.95\right)$ were reported between SL and SWi of $P$. caerulea in the Mediterranean was found by Bouzaza and Mezali (2018). These findings are consistent with our results. Unlike these findings, Belkhodja and Romdhane (2012) reported that curvilinear regression equations between morphometric measures for Mediterranean limpets in Tunisia. Compared with our findings, weaker correlation coefficients $\left(\mathrm{R}^{2}=0.962\right.$ and $\mathrm{R}^{2}=$

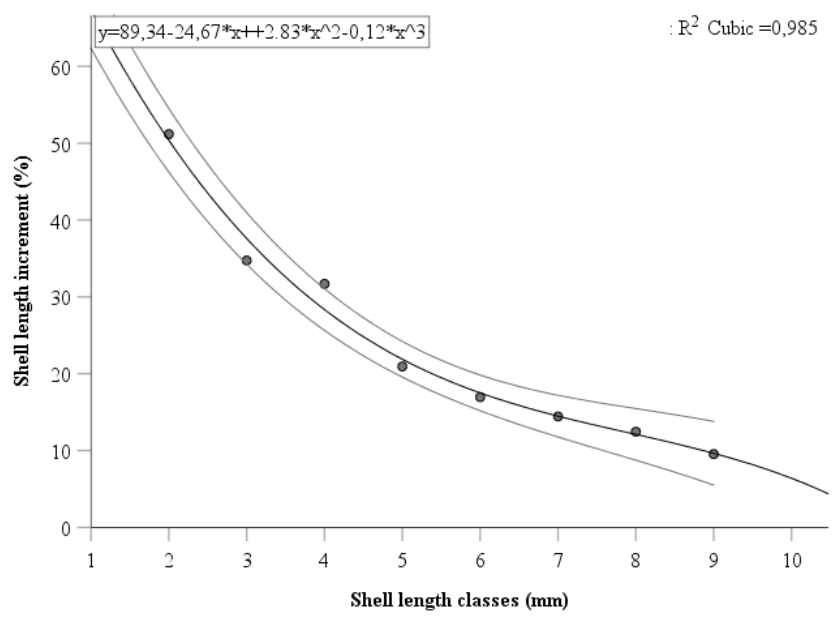

0.908 for sheltered and exposed, respectively) were obtained of morphometric measurements of $P$. caerulea by Vafidis et al. (2020). Patella species may show significant morphological variability depending on environmental variation (Mauro et al., 2003). Correlations among the morphometric parameters are of particular significance in terms of understanding of smoothness of organism shell structure. It should be underlined, however, that big sample sizes could make a slight difference among the correlations that are significant (Aydin et al., 2014). The relationship of SL with TW and the linear relationship of SL with SWi and SH are presented in Figure 5. However, the b value of SL and TW of individuals was found as 3.09 (positive allometry). Considering the growth value $(b>3)$, it can be said that the sampled limpets have well enough environmental conditions, and the total growth of the individuals is provided as required. The b value was reported as 2.89 between SL and TW in the exposed site in Pagasitikos Gulf. Isometric growth type for SL and TW was reported by Vafidis et al. (2020). This value may vary depending on many conditions such as the number of samples, catch season, characteristics of the aquatic ecosystem, gonadosomatic index, and nutrition (Bagenal, 1978).

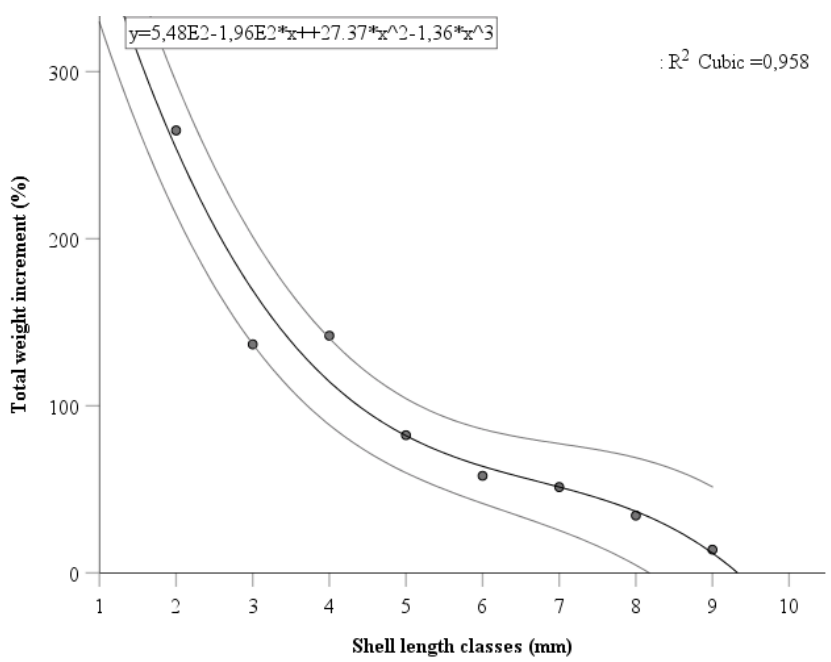

Figure 4. Growth increments (\%) indicating the size classes for the Mediterranean limpets, where shell length from 5.0 to 49.9 mm are represented as 1 to 10 . Grey lines in the graph represent the mean confidence intervals.

Table 4. Pearson correlation coefficients among morphometric variables for P. caerulea

\begin{tabular}{|c|c|c|c|c|c|c|}
\hline Variables & SL & $\mathrm{SW}_{\mathrm{i}}$ & SH & TW & $\mathrm{SW}_{\mathrm{e}}$ & MW \\
\hline SL & 1 & & & & & \\
\hline $\mathrm{SW}_{\mathrm{i}}$ & 0.982 & 1 & & & & \\
\hline $\mathrm{SH}$ & 0.910 & 0.913 & 1 & & & \\
\hline TW & 0.899 & 0.904 & 0.896 & 1 & & \\
\hline
\end{tabular}



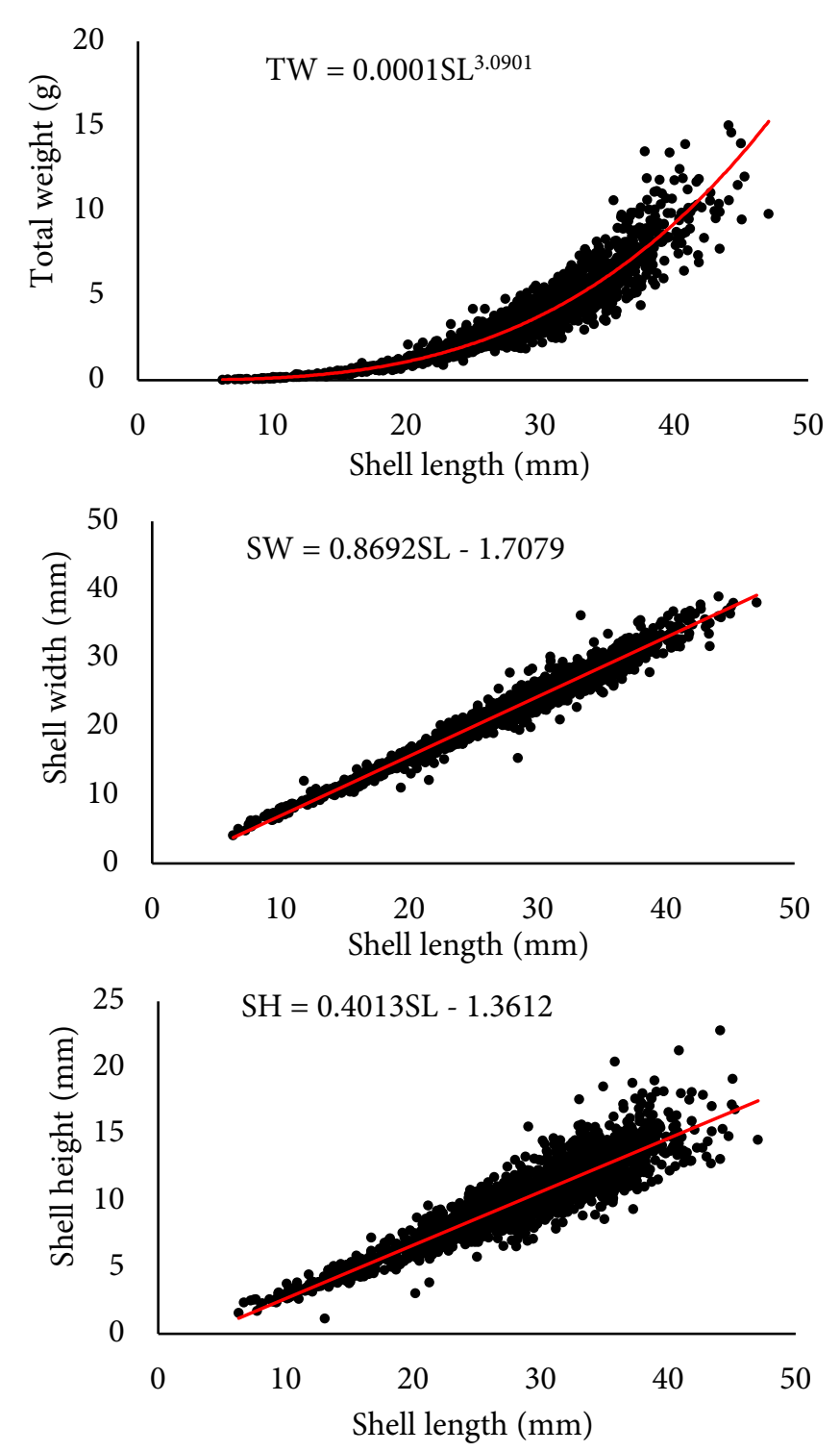

Figure 5. Nonlinear regressions SL-TW, linear regression SLSWi and SL-SH for P. caerulea from the study area $(\mathrm{N}=1380)$. The red lines represent the regression curve.

\section{Condition Factor (K)}

The mean condition factor $(\mathrm{K})$ value was calculated as 14.2 for sampled individuals from the study area. The maximum $\mathrm{K}$ value occurred in June with 15.47, whereas the minimum $\mathrm{K}$ value occurred in December with 12.79. A significant increase in the condition of the individuals was observed in the summer with 15.03 (Figure 6). The mean $\mathrm{K}$ value of individuals was significantly different by monthly $\left(\chi^{2}=164.21 ; \mathrm{df}=11 ; .001\right)$. The highest condition factor can signify the period before spawning in gastropods; water temperature may also affect both the index and reproduction of Patella species (Fretter and Graham, 1976; Vafidis et al., 2020). Based on this statement, it was seen that the increase in the $\mathrm{K}$ value before the ovulation period was significant. Thus, it was determined that the spawning season started in October and ended in November.
The maximum and minimum $\mathrm{K}$ value of $P$. caerulea was reported as $41.20 \pm 1.18$ in winter and as $30.46 \pm 1.54$ in autumn, respectively, by Küçükdermenci et al. (2017). Vafidis et al. (2020) conducted that the maximum $\mathrm{K}$ value occurred in April (32.762 \pm 7.38 ), whereas the minimum $\mathrm{K}$ value occurred in February (26.58 \pm 4.47$)$. The findings of our study were lower than the findings in other studies. Factors, such as different areas, spawning periods, and water parameters, may cause monthly changes in the condition of the limpets (Fretter \& Graham, 1976; Belkhodja et al., 2011).

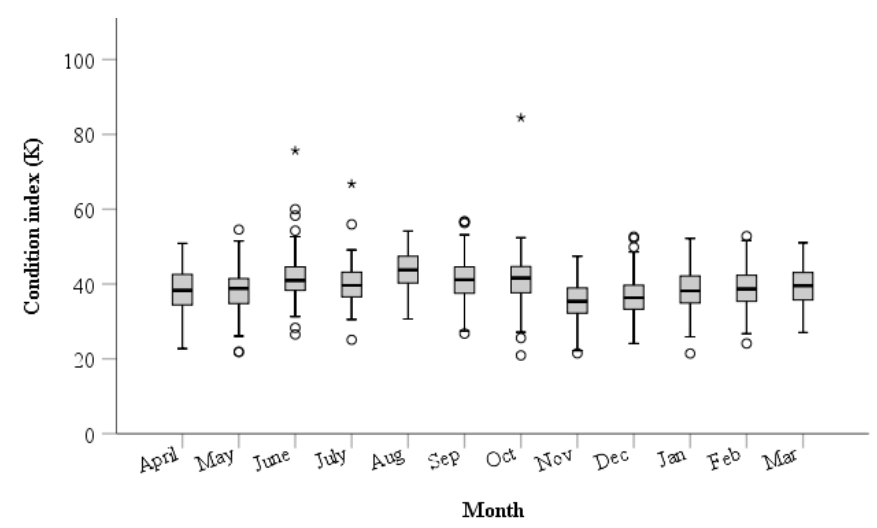

Figure 6. Boxplot of the monthly condition factor $(\mathrm{K})$ for the $P$. caerulea. Horizontal lines in the boxes represent the mean values, and whiskers represent the standard deviations. Error bars represent $95 \%$ confidence intervals.

\section{Reproductive Characteristics}

Ovigerous females were observed for only two months (October and November), implying that spawning takes place for quite a short period for $P$. caerulea. The overall sex ratio of all individuals was calculated as 1:1.93 (M/F), with a significant deviation from the expected $1: 1$ ratio $\left(\chi^{2}=29.19 ; \mathrm{df}=1 ; .05\right)$ in the spawning period. The GSI values of $P$. caerulea ranged from 1.41 to $12.32 \%$, with a mean value of $5.69 \%$. It has been reported that the Mediterranean limpets spawn period is in winter in south Eastern Australia (Parry, 1982), whereas in Eastern Tunisian coasts was between February and May (Gharred et al., 2019). These values are different from those obtained in the present study, suggesting that the regional differences may play a significant role in the spawning period. The fecundity of 26 ovigerous females ranged from 39,773 to 127,273 with an average value of $90,983 \pm 28,675 \mathrm{eggs} / \mathrm{g}$. The egg diameter of samples ranged between $115.0 \mu \mathrm{m}$ and $242.5 \mu \mathrm{m}$ (mean 160.6 $\mu \mathrm{m})$. Gharred et al. (2019) reported the mean egg diameters for three sites on the eastern Tunisian coast as 56.93, 41.22 and $40.71 \mu \mathrm{m}$, respectively. The egg diameters of Mediterranean limpets are unequivocally higher than those obtained in the 
present study. The present monitoring study suggests that reproduction parameters of Mediterranean limpets may exhibit variations depending on the regions.

\section{Conclusion}

In conclusion, due to its ever-changing spatiotemporal structure, the Black Sea should be closely monitored in terms of biodiversity, food chains and ecosystems. Thus, it is essential and valuable to know the current status, growth, and reproductive performance of available populations. This study presents baseline information on the Mediterranean Limpets population in this area, where no studies have been carried out. This study assessed growth, morphometric parameters and population aspects of the Mediterranean limpet, contributing valuable new data on $P$. caerulea along the Black Sea coastal zones.

\section{Acknowledgements}

No funding was received to assist with the preparation of this manuscript. The authors declare that for this article they have no actual, potential, or perceived conflict of interests.

\section{Compliance with Ethical Standards}

\section{Authors' Contributions}

All authors contributed to the study conception and design. Material preparation, data collection and analysis were performed by MA, AES and UK. All authors read and approved the final manuscript.

\section{Conflict of Interest}

The authors declare that they have no conflict of interest.

\section{Ethical Approval}

Ethics committee approval is not required. All authors declare that this study does not include any experiments with human or animal subjects. All applicable international, national, and institutional guidelines for the care and use of animals were followed by the author.

\section{References}

Akşit, D., \& Falakalı Mutaf, B. (2007). The external morphology of the gill of Patella caerulea L. (Mollusca: Gastropoda). Turkish Journal of Zoology, 35, 603-606. https://doi.org/10.3906/zoo-0907-82
Ayas, D., Almış, M., \& Kaya, U. L. (2008). Distribution and morphometric characteristics of Patella (Archaeogastropoda) in Mersin-Karaduvar region of the Northeastern Mediterranean Sea. Journal of FisheriesScience.com, 2, 570-575.

Ayas, D. (2010). Distribution and morphometric characteristics of Patella species (Archaeogastropoda) in MersinViransehir region of the Northeastern Mediterranean Sea. Journal of FisheriesSciences.com, 4, 171-176.

Aydın, M., Karadurmuş, U., \& Tunca, E. (2014). Morphometric aspects and growth modeling of exotic bivalve blood cockle Scapharca inaequivalvis from the Black Sea, Turkey. Biologia, 69, 1707-1715. https://doi.org/10.2478/s11756-014-0476-3

Bagenal, T. B. (1978). Methods for Assessment of Fish Production in Freshwaters (3th ed.). Blackwell Scientific. $300 \mathrm{p}$.

Bat, L., Gündoğdu, A., Sezgin, M., Çulha, M., Gönlügür, G., \& Akbulut, M. (1999). Acute toxicity of zinc, copper and lead to three species of marine organisms from Sinop Peninsula, Black Sea. Turkish Journal of Biology, 23, 537544.

Belkhodja, H., Jaafoura, M. H., Missaoui, H., \& Romdhane, M. S. (2011). Histological investigation of the reproductive cycle of the limpet Patella caerulea Linnaeus, 1758. Cahiers de Biologie Marine, 52, 279-290. https://doi.org/10.21411/CBM.A.C8C14E76

Belkhodja, H., \& Romdhane, M. S. (2012). Etude morphométrique du mollusque gastéropode Patella caerulea Linnaeus, 1758 des côtes nord de la Tunisie. Bulletin de l'Institut National des Sciences et Technologie de la Mer, 39, 15-23.

Bouzaza, Z., \& Mezali, K. (2018). Discriminant based study of the shell morphometric relationships of Patella caerulea (Gastropoda: Prosobranchia) of the western Mediterranean Sea. Turkish Journal of Zoology, 42, 513522 .

Christiaens, J. (1973). Révision du genre Patella (Mollusca, Gastropoda). Bulletin du Museum National d'Histoire Naturelle, 182, 1305-1392.

Crothers, J. H. (1983). Variation in dog whelk shells in relation to wave action and crab predation. Biological Journal of the Linnean Society, 20, 85-102. https://doi.org/10.1111/j.1095-8312.1983.tb01591.x 
Çulha, M., \& Bat, L. (2010). Visible decline of limpet Patella caerulea Linnaeus, 1758, a biomonitor species, at the Sinop peninsula and vicinity (the Southern Black Sea, Turkey). Journal of Environmental Protection and Ecology, 11, 1024-1029.

Düzgüneş, O., Kesici, T., \& Gürbüz, F. (1983). İstatistik Metodları I [Statistical Methods I] (1st ed.). Ankara Üniversitesi Ziraat Fakültesi Yayınları.

Erkoyuncu, İ. (1995). Balıkçılık Biyolojisi ve Populasyon Dinamiği [Fisheries Biology and Population Dynamics] (1st ed.). Ondokuz Mayıs Üniversitesi Yayınları.

Espinosa, F., Guerra García, J. M., Fa, D., \& García Gómez, J. C. (2006). Effects of competition on an endangered limpet Patella ferruginea (Gastropoda: Patellidae): Implications for conservation. Journal of Experimental Marine Biology and Ecology, 330, 482-492. https://doi.org/10.1016/j.jembe.2005.09.020

Fretter, V., \& Graham, A. (1976). The prosobranch mollusks of Britain and Denmark. Journal of Molluscan Studies Supplement, 1, 1-37.

Gharred, T., Helaoui, A., Mannai, R., \& Jebali, J. (2019). Effect of multiple pollution on the cholinesterase activity, morphometry and reproduction performance of Patella caerulea collected from eastern Tunisian coasts. Cahiers de Biologie Marine, 60, 11-20. https://doi.org/10.21411/CBM.A.132317A6

Hakenkamp, C. C., \& Morin, A. (2000). The importance of meiofauna to lotic ecosystem functioning. Freshwater Biology, 44, 165-175. https://doi.org/10.1046/j.13652427.2000.00589.x

Hamad, S. H., Ali, S. M., Ali, R. A. S., \& Alfergani, E. S. (2019). Distribution and morphological traits of Patella species in Al-Hanya rocky intertidal coast, eastern Libya Mediterranean Sea. Proceedings of the International Biodiversity and Ecology Sciences Symposium, Turkey, pp. 89-100.

Jones, C. M., Mc Conaugha, J., R., Geer, P. J., \& Prager, M. H. (1990). Estimation of spawning stocks size of blue crab, Callinectes sapidus, in Chesapeake Bay, 1986-1987. Bulletin of Marine Science, 46, 159-169.

Katsanevakis, S., Lefkaditou, E., Galinou Mitsoudi, S., Koutsoubas, D., \& Zenetos, A. (2008). Molluscan species of minor commercial interest in Hellenic seas distribution, exploitation and conservation status. Mediterranean Marine Science, 9, 77-118. https://doi.org/10.12681/mms.145
Küçüdermenci, A., Lök, A., Kırtık, A., \& Kurtay, E. (2017). The meat yield variations of Patella caerulea (Linnaeus, 1758) in Urla, Izmir Bay. Acta Biologica Turcica, 30, 174 177.

Kwei, E. A. (1978). Size composition, growth and sexual maturity of Callinectes latimanus (Rath) in two Ghanaian lagoons. Zoological Journal of the Linnaean Society, 64, 151-175. https://doi.org/10.1111/j.10963642.1978.tb01066.x

Le Cren, E. D. (1951). The length-weight relationships and seasonal cycle in gonad weight and condition in perch (Perca fluviatilis). Journal of Animal Ecology, 20, 201219. https://doi.org/10.2307/1540

Lopez, F. J. S., Garcia, M. D. G., Vidal, J. L. M., Aguilera, P. A., \& Garrido Frenich, A. (2004). Assessment of metal contamination in Donana National Park (Spain) using crayfish (Procamburus clarkii). Environmental Monitoring and Assessment, 93, 17-29. https://doi.org/10.1023/B:EMAS.0000016789.13603.e5

Mauro, A., Arculeo, M., \& Parinello, N. (2003). Morphological and molecular tools in identifying the Mediterranean limpets Patella caerulea, Patella aspera, Patella rustica. Journal of Experimental Marine Biology and Ecology, 295, 131-143. https://doi.org/10.1016/S00220981(03)00291-0

Menge, B. A. (2000). Top-down and bottom-up community regulation in marine rocky intertidal habitats. Journal of Experimental Marine Biology and Ecology, 250, 257-289. https://doi.org/10.1016/S0022-0981(00)00200-8

Navarro, P. G., Ramirez, R., Tuya, F., Fernandez-Gil, C., Sanchez-Jerez, P., \& Haroun, R. J. (2005). Hierarchical analysis of spatial distribution patterns of patellid limpets in the Canary Islands. Journal of Molluscan Studies, 71, 67-73. https://doi.org/10.1093/mollus/eyi009

Öztürk, B., \& Ergen, Z. (1996). Patella species (Archaeogastropoda) distributed in Saros Bay (Northest Aegean Sea). Turkish Journal of Zoology, 23, 513-519.

Parry, G. D. (1982). Reproductive effort in four species in intertidal limpets. Marine Biology, 67, 267-282. https://doi.org/10.1007/BF00397667

Pauly, D. (1980). A Selection of Simple Methods for the Assessment of Tropical Fish Stocks. FAO Fisheries Technical Paper. Food and Agriculture Organization of the United Nations, Rome, Italy. 52 pp. 
Prusina, I., Sarà, G., de Pirro, M., Dong, J. W., Han, G. D., Glamuzina, B., \& Williams, G. A. (2014). Variations in physiological responses to thermal stress in congeneric limpets in the Mediterranean Sea. Journal of Experimental Marine Biology and Ecology, 456, 34-40. https://doi.org/10.1016/j.jembe.2014.03.011

Prusina, I., Peharda, M., Ezgeta Balic, D., Puljas, S., Glamuzina, B., \& Golubic, S. (2015). Life history trait of the Mediterranean keystone species Patella rustica: Growth and microbial bioerosion. Mediterranean Marine Science, 16, 393-401. https://doi.org/10.12681/mms.1121

Ricker, W. E. (1975). Computation and Interpretation of Biological Statistics of Fish Populations (1st ed.). Bulletin of the Fisheries Research Board of Canada.

Silva, A. C. F., Hawkins, S. J., Boaventura, D. M., \& Thompson, R. C. (2008). Predation by small mobile aquatic predators regulates populations of the intertidal limpet Patella vulgata (L.) Journal of Experimental Marine Biology and Ecology, 367, 259-265.
Sokal, R. R., \& Rohlf, F. J. (1969). Introduction to Biostatistics (1st ed.). W.H. Freeman and Company.

Sotorelli, M. M., \& Margotrigiano, G. O. (2005). Bioindicator organisms: Heavy metal pollution evaluation in the Ionian Sea (Mediterranean Sea Italy). Environmental Monitoring and Assessment, 102, 159-166. https://doi.org/10.1007/s10661-005-6018-2

Vafidis, D., Drosou, I., Dimitriou, K., \& Klaoudatos, D. (2020). Population characteristics of the limpet Patella caerulea (Linnaeus, 1758) in Eastern Mediterranean (Central Greece). Water, $\quad 3304$. https://doi.org/10.3390/w12123304 